Marquette University

e-Publications@Marquette

Summer 1998

The History Never Written: Bards, Druids, and the Problem of Antiquarianism in Poly Olbion

John E. Curran Jr.

Follow this and additional works at: https://epublications.marquette.edu/english_fac

Part of the English Language and Literature Commons 


\title{
The History Never Written: \\ Bards, Druids, and the Problem of Antiquarianism in Poly Olbion
}

\author{
by JOHNE. CURRAN, JR.
}

The rise of antiquarianism in late Elizabethan/early Jacobean England posed a threat to the common and traditional notion of continuity through time of British institutions and culture, including the transmission of historical texts. This threat was a major preoccupation for the poet Michael Drayton, and his response to it can be examined in bis depictions of bards and druids in Poly Olbion. Conservatives in the historiographical debate put forth these ancient British poet/priests as an explanation for how ancient British history could have been transmitted through the centuries. But while Drayton in the Poly Olbion certainly uses bards and druids in a concerted attempt to imagine continuity, be reveals some latent suspicions of the truth - that ancient British culture was irretrievably lost.

My Histories notwithstanding begin at Julius Caesar.

- Edmund Bolton, Hypercritica (1618)

Into Drayton, English as he was, had sunk the Renaissance feeling of the wreck and destruction accomplished by Time upon beauty, and power, and noble visible monuments, and the glory of the great.... He now turns, in the wake of Camden, to the huge task of collecting the memories and sagas of Great Britain. He will fight with Time and save Antiquity, which men are disregarding.

- Oliver Elton, Michael Drayton: A Critical Study (1966), 110

W ritten some time back by the critic Oliver Elton, this statement on the intention behind Drayton's Poly Olbion touches on one of the poem's essential dilemmas, a problem with which, as Elton says, many in Drayton's age were preoccupied. As learned men became obsessed with antiquity, they formulated their obsession according to an irreconcilable paradox: they simultaneously lamented the passing of antiquity - the "wreck and destruction accomplished by Time" - and attempted to reclaim it, to "save Antiquity." Lamenting the loss of the past is as much as to admit that it is past; but "collecting the memories and sagas" of the nation presupposes that there are, in fact, materials to collect and memories that have been remembered - such a project necessarily denies that time has wrecked and destroyed everything. This paradox, as J.G.A. 
Pocock has shown, ${ }^{1}$ touches on that fundamental problem of the English Renaissance, the struggle to imagine that British institutions and culture, such as the Ancient Constitution, had survived unchanged through time. As Claire McEachern has recently demonstrated, Drayton exhibits an awareness of this paradox, and an ambivalent attitude about the newly realized problem of recordlessness. ${ }^{2}$ I will elaborate on this observation and argue that Drayton was a man divided between the sensibilities of the monumental historian and the antiquarian. Deeply conflicted about recent developments in historiography, he was dismayed at what was emerging as the truth about his nation's ancient past: that before the Romans, nothing was known, and anything after their arrival was known only because the Romans had vouchsafed to tell it. The poet was facing the awful prospect that there was nothing further to collect, and that nothing further had been remembered. My purpose here is to trace Drayton's feelings about this problem through the Poly Olbion by focusing on his love for bards and druids, creatures born from the Renaissance discovery of Roman Britain. For Drayton, bards and druids represented the preservation of ancient British culture from prehistoric times through to his own age; and yet, as I hope to show, bards and druids also represented the poet's anguished sense that this culture had not been preserved at all.

Before I proceed, I must first define "antiquarian" and "monumental historian." These terms are developed by Richard F. Hardin in his analysis of Drayton's analogy on time at the end of Song 10; Hardin uses "antiquarian" to describe pessimism about drawing upon the past as a guide for the present, and "monumental historian" to describe optimism. ${ }^{3}$ Indebted as I am to Hardin for identifying these useful terms, they may nevertheless be put to greater use. Here, by antiquarian I mean that serious, methodical mindset we associate with William Camden and his followers, which privileges documented and documentable, verified and verifiable historical sources. The antiquar-

${ }^{1}$ Pocock, $4,36$.

${ }^{2}$ McEachern, 181-82. For McEachern, Drayton's attitude in Poly Olbion is slanted toward a concession to time; for her, the prevailing sense in the poem is that "All is temporary" (166). My argument calls for a Drayton who is much more insistent on battling time, and who only grudgingly and regretfully yields to it.

${ }^{3}$ Hardin, 61-66. All references to the Poly Olbion are to Song and line numbers, except those to Selden's commentaries, which are to page number, and are taken from Hebel's edition, vol. 4. References to Drayton's other works shall refer to volume and page numbers from this edition. 
ian, concerned with the tangible and findable, is willing to concede that there is a point in history beyond which he knows nothing, and, while he laments the loss of past cultures to the ravages of time, he is nevertheless able to acknowledge that such a loss has occurred, and to declare that time has won. From the point of view of the monumental historian, however, such a surrender is unacceptable. Charged with glorifying the history of their people and with conveying the memory of all their deeds to posterity so that the great may live forever, monumental historians cannot brook large gaps in their nation's history, nor can they allow a foreign history to take the place of their own; they cannot admit to a forgotten past.

The problem comes when the two points of view converge, because the sensibility of the antiquarian demands of the monumental historian some proof, some verification, for his claims to an unforgotten past with no gaps. Drayton epitomizes this divided historical consciousness. Last of the important defenders of Geoffrey of Monmouth's British History, ${ }^{4}$ he was a monumental historian at heart. He clung to the Galfridian tradition because it gave his beloved nation a claim to an illustrious - and, importantly, a very old - heritage. The notion of permanence through time of British culture had impressed itself upon him, and for Drayton the urge to imagine continuity with ancient Britain was particularly strong. And yet the poet was also a great admirer and friend of Camden, and Camden's Britannia helped inspire his magnum opus. Drayton thus certainly felt the pull of the new, humanist historical methodology, and it upset his convictions that time could be overcome.

This tension in Drayton between the antiquarian and the monumental historian is worked out most poignantly in his bards and druids. Scholars, particularly Geoffrey G. Hiller, have taken notice of the special attention Drayton devotes to these figures. ${ }^{5}$ No scholar, however, has explored fully their role in Drayton's historical point of view. As we shall see, on the one hand bards and druids provided a solution to the problem of antiquarianism: they were argued to have been the purveyors of British culture by means of oral tradition and of books now lost. Through these historians, continuity with antiq-

${ }^{4}$ For Drayton as the last important post-Camden believer in Geoffrey, see Brinkley, 62; Kendrick, 1950, 103-04. Drayton's stubborn credulity in the British History is assumed by Hardin, 48-49; and by Newdigate, 169-71. For studies more suspicious of Drayton's credulity, see Herendeen, 152; Ferguson, 100, 128.

${ }^{5}$ Hiller, 1-15. See also Jonas, 65, 73; Grundy, 142; Owen, 46-50; Piggot, 139. 
uity could be assumed even though no history was extant up until Geoffrey of Monmouth. But on the other hand, Drayton seems to sense that this assumed, conjectural historical tradition, imagined as culminating in Geoffrey, cannot satisfy the demands of the antiquarian. A hypothetical history is, finally, insufficient to defeat time. Because it was never written down, the history is, for all practical purposes, a history never written - that is, a history that we may as well assume was never composed at all.

\section{I}

Renaissance scholars in England in the sixteenth and early seventeenth centuries were able to locate two important statements from antiquity concerning the possibility of gaining first-hand knowledge of the ancient Britons. By "first-hand" is meant any history recorded by the Britons themselves about their own pre-Roman, Romano-British, or pre-Saxon culture. The two ancient authorities on this question were Julius Caesar and the sixth-century British writer Gildas. Julius Caesar, commenting on the druids, designated them as the guardians of all aspects of ancient Celtic culture. This guardianship, however, was contingent upon their survival as an elite, protected, and isolated institution; for, although Caesar tells us they knew something of Greek letters, the most vital aspects of druidical culture lore, history, literature - were by law transmitted orally and recorded by memory alone. The dual purpose of this practice, says Caesar, was to sharpen the memory and to maintain exclusive access to the materials. ${ }^{6}$ But at once we can see the problem: as go the druids, so goes any history they had preserved. Meanwhile, Gildas, the oldest British author available, told Renaissance Englishmen that if ever any British histories had been written, they were now lost, destroyed, or carried away during the course of Britain's many turmoils; Gildas admitted that anything he knew about the ancient Britons came from foreign historians, by transmarina relatione. ${ }^{7}$ These statements by Caesar and Gildas were to form the basis for antiquarian thought on Roman and pre-Roman Britain in the English Renaissance. Discerning scholars, beginning with Polydore Vergil, ${ }^{8}$ were able to abandon the notion that British lore had been successfully

${ }^{6}$ Caesar, 339. Caesar's is the first and best account of the druids, the only other instructive accounts coming from Pliny; see Pliny, 4:549-51, 7:75-77, 8:217-19, 8:287.

${ }^{7}$ Gildas, 90.

${ }^{8}$ See Polydore Vergil, 33. 
transmitted from the supposed era of the fall of Troy down to the present. Caesar and Gildas legitimized the urge to concentrate on the available records - the histories in the Roman authors - and to ignore the history which was not there.

At the head of the antiquarians was Camden who, as Arthur B. Ferguson remarks, "was more interested in the antiquities of those ages for which he had hard evidence" - ages like Roman Britain, the hard evidence for which was classical historiography. Writing on the prospects for determining the character of the first inhabitants of Britain, Camden sets forth what may be considered the antiquarian manifesto: "Moreover the Druidae, who being in olde time the Priests of the Britans and Gaules, were supposed to have knowen all that was past; and the Bardi, that used to resound in song all valorous and noble acts, thought it not lawfull to write and booke any thing. But admit they had recorded ought; in so long continuance of time, in so many and so great turnings and overturnings of States, doubtlesse the same had been utterly lost, seeing that the very stones, pyramides, obelisks, and other memorable monuments, thought to be more durable than brasse, have yeelded long agoe to the iniquitie of time." Thus Camden uses first Caesar, then Gildas, to conclude that no authentic trace of ancient British life, to which the Britons themselves bear witness, may be thought to exist; the conclusion is, time has won, and continuity with the past may not be assumed. Camden goes on to explain that men of subsequent ages, who "desired gladly to supplie these defects," fabricated a history to suit themselves. In other words, Galfridian mythology was produced during the middle ages in order to fill, as entertainingly as possible, the gaps in the nation's heritage. ${ }^{10}$ This awareness of and detachment from the medieval need to fill gaps, this yielding of the victory to time, and this reliance on credible, available sources, is what the antiquarian mindset was all about. It was a mindset which gained considerable momentum in the early seventeenth century, as prominent writers like John Speed, Samuel Daniel, and John Selden - Drayton's friend, and the author of the Illustrations to the Poly Olbion - followed Camden's sceptical out-

${ }^{9}$ Ferguson, 94.

${ }^{10}$ Camden, 1610, 4. 
look on continuity and shared his view that British history essentially began with Caesar's invasion. ${ }^{11}$

Working contemporaneously with these antiquarians, Drayton felt compelled to respond to their formidable affront to the idea of continuity; and so, into the Poly Olbion he incorporated his two famous, passionate defenses of the British History. Each one of these defenses is placed near the end of a long speech by a river: the river Dee and the river Wye both conclude their orations with apologies for Geoffrey of Monmouth (10.219-307; 6.275-340). In the defenses, we get a strong impression of Drayton's conflicted state as he tried to combat the problem of antiquarianism, and we also notice how central are bards and druids in his thinking about it.

Dee opens his defense by replying to the objection that the Roman histories are silent on the Trojan stock of Britain. The river argues that "our ancient British Rimes," which "our noble Bards ... so divinely sung" (238-39), are actually older than any histories of the Romans, and more factual than the "fabulous" tales of the Greeks (254-56). What warrants this claim? "Proofe we can produce" (241), answers Dee. The classics are, of course, Drayton's main adversary. Their exclusive claim to an age-old civilized life - a life about which Renaissance people could actually learn something, because it had produced texts - offends his monumental feelings; things British must be the oldest in the world, they must be true, and we must never have lost access to them: "A thousand ling'ring yeeres, our Prophets cleerely song" the national annals (247). But is this hypothetical bardic oral tradition the extent of the "proofe we can produce"? Is there no tangible production, no text, to be found?

When Dee moves on from bards to the druids, Drayton finds himself depending ever more heavily on conjecture. Dee recites a second objection to the Brute, specifically "that we shewe no Booke our Brutus to approve" (261). Dee counters that this is because the druids "To letters never would their mysteries commit" (267). This druidic law, we are told, instead of being a liability is actually an aid to textual continuity. Books, Dee tells us, are quite vulnerable to the rav-

${ }^{11}$ For antiquarian statements against the prospect of continuity from the druids, see Speed, 157; Daniel, 4:89-90. For Selden's treatment of druids, see his Analecton Anglo-Britannicon, 2:880-89; Janus, 4, 16-22. On British culture transformed by the Roman conquest, see Janus, 37; for the lack of British sources on ancient Britain, see Janus, Ad Lectorem; Annalecton, 2:869. For Selden's scepticism about continuity and his emphasis on available records, see McEachern, 177-81. 
ages of time: "As what so great a Work, by Time that is not wrackt?" (273). Foolish Romans, to entrust their histories to such a fragile medium! The oral tradition of the druids is much more durable: "But when we lay it up within the minds of men, / They leave it their next Age; that, leaves it hers agen: / So strongly which (me thinks) doth for Tradition make, / As if you from the world it altogether take, / You utterly subvert Antiquitie thereby" (275-79). British lore, says Dee, like the Old Testament genealogies, has been passed down with absolute precision. This idea of an oral tradition allows Drayton to make the ultimate monumental claim: Time has been "utterly subverted" - the past is present and alive. The irony of this statement is that time has so thoroughly subverted this oral tradition that Drayton requires the aid of a Roman historian to learn that it ever existed at all; the existence of druids, their secret oral tradition, its purpose for exercising the memory - all these concepts, as we have seen, come straight from Caesar and from nowhere else. Here, Drayton attempts to force Caesar's statement on the private, druidic oral tradition to work on behalf of monumentalism; but the poet has ended up merely rephrasing a basic antiquarian point, that because the tradition was oral and private, circulated exclusively among an extinct group of priests, it is now lost.

And so Dee turns to attacking the credibility of the very man from whom he has divined his information: "So barbarous nor were wee as manie have us made, / And Caesars envious pen would all the world perswade" (297-98). Caesar's commentary on his expedition to Britain seems inconsistent, says Dee; how could the Britons be impressively skilled only in warfare? How could their culture be so primitive in other respects? This moment in the speech is quite revealing; even as it questions Caesar, it admits that questioning him is all that can be done. So the Britons weren't exactly as Caesar said; very well then, what were they? Dee can offer bitterness against Caesar's authority, but no comparably reliable alternative to it. Caesar's is the sole text available. Again, Dee's defense affirms the necessity of the available texts even while outwardly trying to circumvent it.

Drayton's "proofe" of continuity turns out to be merely an idea, an imagined tradition based only upon the conceivable instead of on the probable or provable. Indeed, Drayton himself seems to suspect this, for he closes Dee's defense with the analogy on time mentioned earlier: "But, in things past so long (for all the world) we are / Like to 
a man embarqu't, and travelling the Deepe" (308-23). The past is likened to the cliffs on the shore, which grow ever harder to see the further away we sail on the sea of time; until finally, those cliffs are "out of kenning quite": "So, of the Ages past; / Those things that in their Age much to be wondred were, / Still as wing-footed Time them farther off doth beare, / Doe lessen every howre." Dee has shifted his discussion quite suddenly, turning a defense of Geoffrey into a lament about the inaccessibilty of the past; an argument for continuity, it seems, melts into a concession to the fact of discontinuity. It is as if the poet, somehow aware of the weakness of the arguments he so ardently puts forward, leaves an acknowledgment that the gap between past and present widens "every howre."

This reality bothers Drayton in his other, more famous defense of Geoffrey, within the speech of the river Wye in Song 6, which begins: "Heere then I cannot chuse but bitterlie exclame / Against those fooles that all Antiquitie defame." Wye's initial argument is quite tangled:

some credulous Ages layd

Slight fictions with the truth, whilst truth on rumor stayd;

And that one forward Time (perceiving the neglect

A former of her had) to purchase her respect,

With toyes then trimd her up, the drowsie world t'allure,

And lent her what it thought might appetite procure

To man, whose mind doth still varietie pursue;

And therefore to those things whose grounds were verie true,

Though naked yet and bare (not having to content

The weyward curious eare) gave fictive ornament (277-86)

What Drayton seems to mean is that a primitive culture, long ago when it first forged its history, intermingled some falsehoods ("slight fictions") with truth. Then, people of a later era, perceiving this earlier history as somehow inadequate ("perceiving the neglect a former of her had") embellished the history further, in order to glorify itself and interest a bored audience. This means, then, that the history was not passed down intact; instead of each age making sure the next generation gets it right (as Dee argues in Song 10), each successive age takes upon itself the embellishment of the history. Drayton puts forth this argument in order to persuade us that while the British History may be rife with fables, there is a precious grain of truth in it which we should not cast away. In the process, however, the poet has given an account of an unstable, continually changing historio- 
graphical tradition. The version of the history which finally reached Geoffrey could not much resemble what went on two thousand years ago.

Throughout Wye's defense, arguments on behalf of monumental continuity serve only to remind us of our deprivation of sources to corroborate Geoffrey or to shed any light on pre-Roman Britain. The river soon "bitterly exclames" about the unconscionable reliance of present history students on Caesar: "Therefore (in my conceit) most rightlie serv'd are they / That to the Roman trust (on his report that stay) / Our truth from him to learne, as ignorant of ours / As we were then of his; except t'were of his powers: / Who our wise Druides here unmercifullie slew" (305-09). Unpatriotic Englishmen who look to Caesar for their information deserve him, says Wye, because he is a terrible murderer who committed physical and cultural genocide on their own country. He destroyed the druids, writes Wye, "who through the world were reverenced" for their vast learning (316). The problem is, this speech conveys only rage at having to listen to an evil invader like Caesar; it does not deflect the fact of having to listen to him. In fact, the Wye confirms our need for Caesar because she emphasizes the druids' extinction. How can dead druids be expected to pass the history on, intact, through an oral tradition?

Wye goes on to assert Roman ignorance of British annals and failure to learn and preserve them, reflecting Drayton's desire to forward a notion of "privileged information." Caesar "never understood" any aspects of British life, including "our tongue," the heroic songs "which our great bards did sing," and "our former state, beginning, our descent, / The warres we had at home, the conquests where we went" (320-27). The British bardic annals, rich with stories of important events, were unknown to the Romans, who, when they bothered to record anything about Britain, did so only to advance their own glory: "though the Romans here / So noble Trophies left, as verie worthie were / A people great as they, yet did they ours neglect, / Long rear'd ere they arriv'd" (327-30). Drayton has caught himself in a double confession here. First, he admits that the remains of the ancient British past, written and archeological, corroborate only the Roman historical perspective; Roman "Trophies" are all that survive. Second, he admits that anything that could have survived would have survived only by Roman record keeping. It is a shame, he writes, that the Romans "did ours neglect," because their neglect is fatal. Anything which survives does so at Roman discretion. The 
monumental historian in Drayton clings to the idea of an unbroken past, of monuments "rear'd long ere" the Roman occupation; but something else in him seems to concede that this belief is only an idea, a religion of faith.

The final segment of Wye's defense has a similar concession encoded within it. Wye cites the objection that "The Ruines and Records we show, be verie small / To prove our selves so great" (33132). But Wye's rebuttal to her adversaries' point seems not helpful to her case. Wye says that instead of wondering about the scarcity of sources, we should rather wonder that we know anything at all about the ancient Britons, besieged as they were by waves of invading foreign nations, "each like a horrid raine / Deforming her [Britain]" (332-37). In the midst of these invasions was an all-out assault on British learning and record-keeping: "the sacrilegious wrack / Of many a noble Booke, as impious hands should sack / The Center, to extirp all knowledge, and exile / All brave and ancient things, for ever from this Ile" (337-40). We should not wonder, then, that the history is not extant, with this conspiracy to annihilate it. But Drayton, in trying to explain away the scarcity of written sources, finds himself rephrasing the antiquarian credo based on Gildas: British learned culture was truncated by the turmoils of invasion, and its records were destroyed. Purporting to defend Geoffrey by inferring a long tradition validating him, Drayton manages to express only anger at the British nation's lost history. Instead of explaining how it got here, the poet has told us only of his sorrow over its "wrack." As Drayton leaves Wye, he tells us that she sang "Expressing wondrous griefe" (341).

In the two defenses, we see that monumental desire for continuity is repeatedly disturbed by an antiquarian recognition that a history needs documentation, and that the Britons have simply not provided any. Just as Dee's defense gives way to his lamentation over the ravages of time, Wye's defense continually turns arguments in support of Geoffrey into emotional invectives against forces that have conspired to cut off the nation from its own ancient history. We have also seen in examining the two defenses that bards and druids are an integral part of the problem; it is they who comprise Drayton's best evidence for continuity, though they also present an impenetrable mystery by keeping the secrets of the past to themselves for eternity. This ambivalent sense is quite strongly felt in the defenses, but these represent only a small portion of Drayton's obsession with bards and druids. If we look more closely at the poet's bards and druids, we see 
that the struggle between monumental history and antiquarianism is much in evidence.

That Drayton identified personally with bards, as Hiller argues, is beyond question. They were not only poets but also prophets, imbued with supernatural inspiration to see the future as well as the past of their nation. Drayton's ideal of the public vates - ordained with connections to the divine, a glorifier of his people and a teacher of decency - led him to view the Celtic bard as the perfect pattern for the poet. ${ }^{12}$

But bards were vital not only to Drayton's self-image, but also to his monumental purposes: bards were linked to the idea of continuity because they represented victory over time. First, there was their vatic subject matter; in tabulating past as well as future national events, bards were able to overcome time from two directions. Past and future were both alive in the present. Second, there was the fact of their perseverance; past was present in contemporary Welsh poets. The existence of bards was mentioned in the classics, ${ }^{13}$ and one could still meet a live bard here and there in the seventeenth century, still singing in what was supposed to be exactly the same language. ${ }^{14}$ This had much to say on behalf of continuity. These two aspects are apparent in Poly Olbion in Drayton's three important general statements about bards.

The first statement on bards virtually opens the entire poem, as Drayton devotes his invocation to them: "Yee sacred Bards, that to your Harps melodious strings / Sung th'ancient Heroes deeds (the monuments of Kings) / And in your dreadfull verse ingrav'd the prophecies, / The aged worlds descents, and Genealogies" (1.31-34). The ancient history of the Britons, as well as the events of the future, have been "ingrav'd" by the bards - given permanent tabulation, impossible to erase. Drayton then says that he hopes the druidical

${ }^{12}$ Hiller, 1, 5-6. For Drayton and the office of the poet, see also Jonas, 49-54; Grundy, 42, 108-09; Hardin, 107-11.

${ }^{13}$ The most important classical references to the Celtic bards come from Strabo, 2:245; Diodorus Siculus, 3:179; Lucan, 37. It is Lucan who stresses that the bards sung the praises of their famous warriors - i.e., that they recorded a form of history. Modern scholarship has deemed unlikely the presence of any residue of druidic lore in Welsh poetry; see Kendrick, 1927, 27-30. Kendrick's opinion is corroborated by Piggott, 131, 165-66; and by Owen, 31, 193-94.

${ }^{14}$ For the survival of Welsh see Camden, 1984, 22-23. 
doctrine of metempsychosis proves true, so that the spirits of the old bards may be infused within him (35-42). Longing to include himself within the bardic tradition, to be placed as a link in the continuous chain, the monumental historian expresses his wish that the songs of the past, which glorify the nation, be present in him.

In Song 4, Drayton's second major treatment of bards describes the institution as it existed in Wales (171-90). The role of the bards in transmitting British history is again made clear: "in their sacred rage / Recorded the Descents, and acts of everie Age" (171-72). In the course of going over the various conventions and meters of Welsh poetry, Drayton mentions a gathering called the Stevtha, in which bards judge other bards in competition (177-78). This Stevtha is an important concept which recurs in Dee's defense: "But from the first of Time, by Judges Still were heard, / Discreetlie every yeere correcting where they err'd" (10.257-58). In other words, Drayton puts forth the Stevtha as the means by which the history was purely conducted through the centuries; bards listened to other bards and made sure they recited the songs correctly. Of course, this is to make the logical jump that the Stevtha existed in the ancient world, a notion for which, as Selden tells us in his notes to Song 4, there was no evidence (83-84). But no matter. For Drayton, the Stevtha provided a concrete explanation for how old songs could be passed from ear to ear without total corruption. Since those bards always sang, "from those first golden times" (179) to the present, Drayton felt safe in attaching a bardic practice with which he was familiar to the bards of old again, the past was present, the present past. Drayton closes his encomium to bards in Song 4 with admiration at their natural poetic aptitude, so impressive for people who "scarce have seen a Booke" (189). Books are scarcely needed with such enthusiastic students committed to memorizing, carefully and verbatim, the national annals.

Bards get their third extended treatment in the middle of Wye's speech in Song 6 (252-74). Wye's passion for Welsh bards, in fact, seems naturally to move her to "bitterlie exclame" and begin her defense of Geoffrey. Bards are held up as the best illustration of the Britons' ability to survive the upheavals of Roman and Saxon marauders. The British language and culture, through the patriotic zeal and pluck of its noble guardians, remain alive. Not only is this part of the speech calculated to move our British sympathies, but we are also meant to consider that, although the odds were against it, continuity was achieved. The situation was precarious, but the bards have pre- 
served national literary treasures: "O memorable Bards, of unmixt blood, which still / Posteritie shall praise for your so wondrous skill, / That in your noble Songs, the long Descents have kept / Of your great Heroes, else in Lethe that had slept" (259-62). The heroes are not forgotten because of the efforts of the bards. Thus, in Song 6, as in 1 and 4 , bards are strongly argued to be instrumental in establishing continuity with ancient Britain.

And yet the poet deflates these three encomia to the bards by following each one of them with a reminder that the notion of an uncorrupted bardic historical tradition was quite suspicious. ${ }^{15}$ After the invocation in Song 1, when next we hear of the bards they are blamed for our lack of knowledge about such heroes as Arthur: "justlie I may charge those ancient Bards of wrong, / So idly to neglect his [Arthur's] glorie in their Song. / For some aboundant braine, $\mathrm{O}$ there had beene a storie / Beyond the Blind-mans might [i.e. Homer] to have inhanc't our glorie" (3.405-08). Such a reproach of the bards for their negligence affirms that in the competition between Britain and the classics for national prestige, Britain is sorely disadvantaged by its dearth of texts. In Song 4, soon after introducing the Stevtha, Drayton, readying himself to summarize the deeds of Arthur, declares that he cannot reproduce those original bardic songs which glorified the famous king: "To tell each various Straine and turning of their Rimes, / How this in compasse falls, or that in sharpness climes . . Even Memorie her selfe, though striving, would come short: / But the materiall things Muse helpe me to report" (239-44). The "materiall things," naturally, turn out to be the commonplace Arthurian stories found in Geoffrey and in his ninth-century source, Nennius; what relation, we must ask, have they to genuine bardic lore? The Stevtha, it seems, has not prevented the problem that "Memorie" has "come short" of the original sources because the original "Rimes" are unavailable. Finally, we notice that Wye's praise of the bards' perseverance is followed directly by that peculiar first part of her defense, her argument about the "slight fictions with the truth." First the river commends the bards for bravely keeping track of the culture, and then she asks us to believe that some grain of historical truth has survived in spite of their tendency to pile nonsense upon nonsense. And so, in each case Drayton cannot avoid calling into question his own ideal of bardic continuity. Perhaps the bards

${ }^{15}$ Attacks on the reliability of the bards were common; see for example Twyne, 130; Buchanan, 14-15; Harrison, 1:23; Spenser, 5:341-42. 
had made genealogies and prophecies, and perhaps bards live today as they did in Roman Britain - but had the bards passed down, with any accuracy at all, a useful historical text?

Two important factors in Drayton's pondering of this question were Taliesin and Merlin; Drayton shows himself quite interested in the two - or, more properly, three - bards. Taliesin and the two Merlins were developed as a result of Geoffrey of Monmouth's other, lesser known work, the Vita Merlini. Here Geoffrey had, if modern scholarship is correct, rethought the Merlin of his Historia Regum Britanniae after he had read more on Merlin and Taliesin in Welsh sources, and had consequently produced a new Merlin story which featured Merlin as a wildman and as a student of Taliesin. The poem has this new Merlin discuss with Taliesin such matters as natural history and prophecy. Geoffrey had intended his new Merlin to be merely a revised version of his old one, ${ }^{16}$ but his two Merlins were so different that it was thought, thereafter, that two prophet/poets, both named Merlin, had actually lived at different times. Giraldus Cambrensis made the distinction explicit: there were two Merlins, one, born of an incubus, called Merlin Ambrosius, who prophesied in the time of Vortigern (Merlin of the Historia), and another, born in Scotland, called Merlin Caledonius or Sylvester, who prophesied during the reign of Arthur (Merlin of the Vita). ${ }^{17}$

For sixteenth-century monumental historians such as John Bale, John Leland, David Powel, Humphrey Lhuyd, and Thomas Churchyard, ${ }^{18}$ these three bards presented an opportunity; named as poet/prophets, they could be reconceptualized into historians. Gildas had alleged that no British literature was extant until himself, but here was evidence that learned men had existed to shed light on the extremely murky time between the Roman withdrawal and the Saxon conquests. These names afforded something to point to, some note-worthy link, some transition, between the bards mentioned in the classics and the bards who informed Geoffrey. Bale says proudly

${ }^{16}$ See The Vita Merlini. On Geoffrey as probable author - the poem attributes itself to him - see Parry's Introduction, 9-15. On Geoffrey's derivation of his new Merlin from Celtic sources, see Introduction, 13, 15-20.

${ }^{17}$ Giraldus, $125-26$.

${ }^{18}$ Bale, 27-28, 30-31, 33; Leland, 49-50, 55, 58, 83-85; for Leland's borrowings from the Vita, see Vita, 83-85; see Powel, 3-5, 15; Lhuyd, 7 (Lhuyd treats bards in general, not Taliesin or Merlin); Churchyard, 22-27, 46. For a discussion of Powel's book and its use in Poly Olbion, see Crawley, 234-55. For Lhuyd and Churchyard in Poly Olbion, see Moore, 789, 791-94. 
of Taliesin and his pupil Merlin Sylvester that "tradunt veterum annales" to their posterity. It could be assumed that the history had been written, since we knew who the writers were. But alas, Bale concedes to the ultimate problem: "Reliqua eius opuscula, historicorum incuria cum titulis perierunt." The text of the history did not tangibly exist.

This problem vexed John Price, the most capable of Geoffrey's defenders, who also made use of the three bards. Price, like Leland, Lhuyd, Powel, and Churchyard, made the argument of "privileged information," that only British scholars skilled in the British language could have access to British monuments, which had been, says Price, preserved in both written and oral records. After reminding us of Caesar's statement about the druids and Greek letters, Price asserts that "Brytannis longe ante Caesaris tempora non desuerit literarum subsidium," and puts forward druids and bards as the purveyors of British history. A British history the Roman authors never knew was passed down through the centuries, and this chain of information was never broken: "nullum tempus est videre, quo non aliqui scriptores saltem Britannici reperiantur." To solidify the idea of this chain, Price names three of its most prominent links: Taliesin, Merlin Ambrosius, and Merlin Sylvester. In exploiting the three bards as proof for the British History, Price, although he quoted from the Vita, had more at his disposal than this, which was after all merely another Galfridian work. In addition to the Vita, he quotes from the Black Book of Caermarthen (the oldest of the "four ancient books of Wales") and the Hanes Taliesin, two medieval books with no direct link to Geoffrey, and with possible roots in the earliest Welsh poetry. To Price's great satisfaction, poems in these books, the authors of which he assumed unquestioningly to be Merlin and Taliesin, made some brief references to Arthur, and the Hanes even made mention of Troy. ${ }^{19}$ Here

${ }^{19}$ Price, 3, 9. For Taliesin and the Merlins as heirs to the druids, see 10-11. For Price's possession of the Black Book of Caermarthen, the earliest of the so-called "four ancient books of Wales, "and other provenancial details about it, see Skene, 1:1-3, 2:31520. Skene dated this manuscript to be of the twelfth century (3), but the poems in it may well have been composed at a much earlier time; they are supposed to be of the sixth century. The Hanes Taliesin (also called the History or Tale of Taliesin, and not to be confused with The Book of Taliesin, another of the "four ancient books") was said by its sixteenth-century transcriber, Ellis Gruffydd, to be in wide circulation in his time; hence we have some explanation for Price's knowledge of it. The Hanes, like the Black Book, is supposed to be, and may be, very old. See Ford, 1992, 46. Also helpful is Ford's translation of the Hanes, Ford, 1977, 159, 164-81. The following is a guide to 
was some credibility for the theory of "privileged information," that there was more to Cambro-British literature than most people knew. But brief mentionings do not a history make, and although Price could use the two old Welsh books to support the existence of Arthur, the Black Book and the Hanes could not account for the great body of Galfridian chronology. The books suggested that someone sometime had recorded something in British about events surrounding the supposed time of Arthur; they could suggest nothing about the vast period of time preceding that of their alleged composition. And as for the ancient oral tradition, which was supposed to have informed these books and Geoffrey, as Ferguson notes, Price's exercise was "largely theoretical," at best "reasonable conjecture." ${ }^{.20}$ It did not afford Renaissance scholars a text with which to corroborate Geoffrey, or unveil the mysteries of pre-Roman or Roman Britain.

The notion of Taliesin as a hero-bard, overcoming both past and future time, has a significant presence in Poly Olbion; but did Drayton fully believe in Taliesin as a force for continuity? Drayton's interest in Taliesin as a possible source for the British History was shared by Selden. In the Poly Olbion, Drayton's illustrator seems to believe that Taliesin was a real author, and that his writings may have supported, to some extent, the existence of Arthur. In his introductory essay, "From the Author of the Illustrations," Selden asks, "How then are they, which pretend Chronologies of that Age [the pre-Roman era of British history] without any Fragment of Authors before Gildas, Taliessin and Nennius (the eldest of which was since D. of Christ) to be credited?" Selden includes Taliesin in a group of authors who are too late to corroborate the Brutus myth; nevertheless, he is named as an extant author here, and subsequently in two of Selden's illustrations $(21,83)$.

Selden, however, does not seem to know of Taliesin except as he was described and excerpted by Price, whereas Drayton's conception of Taliesin is more complicated. That the poet knew Price is without

Price's references to the supposed works of Merlin and Taliesin: on the mention of Troy, see Price, 59, from Hanes, 78, trans. Mabinogi, 173; on Arthur, see Price, 120-21, from Hanes, 74-75, trans. Mabinogi, 170; a conversation between Merlin and Taliesin, see Price, 121, from Black Book poem \#1, Skene, 2:5, trans. 1:370; again on Arthur, see Price, 122-23, from Black Book poem \#22, Skene, 2:38, trans. 1:267; a religious hymn, see Price, 123, from Black Book poem \#12, Skene, 2:13, trans. 1:512; on Avalon, see Price 137-38, from Vita 83-85.

${ }^{20}$ Ferguson, 96-97. 
doubt; but how much did he know about old Welsh literature? ${ }^{21}$ Of course, whatever he could have known would not have provided him with a source for Roman or pre-Roman Britain. As we saw in discussing Price, the oldest Welsh poetry is no older than the sixth century, and treats only current events. But if Drayton at least saw some old medieval poetry of Wales, he could be comforted that the Britons had produced something tangible resembling a historical text, and that the idea of Taliesin writing something was more than just an idea. What had Drayton seen? This question is tantalizingly difficult, if not impossible, to answer. One would have to trace the distribution of copies of poems - such as those found in the "four ancient books of Wales" - in the sixteenth century, and then gauge the probability that Drayton could have had access to them; neither task seems performable.

But although internal evidence appears to be our only guide, at least one scholar may have found some support for Drayton's acquaintance with old Welsh poetry. A.L. Owen, in trying to find a source for Drayton's strange association of druidical prophecy with the river Parret, believes the source may derive ultimately from the Book of Taliesin, one of the "four ancient books." The passage in Song 3 runs as follows:

For, from the Druides time there was a prophecie,

That there should come a day (which now was neere at hand

By all forerunning signes) that on the Easterne Strand,

If Parret stood not fast upon the English side,

They all should be supprest: and by the British pride

In cunning over-come; for why, impartiall Fate

(Yet constant alwaies to the Britains crazed state)

Forbad they yet should fall; by whom she meant to showe

How much the present Age, and after-times should owe

Unto the line of Brute. (374-83)

Drayton also ascribes to the Dee a similar prophecy (10.205-08), on the authority, says Owen, of Giraldus Cambrensis. But there was no apparent authority for the prophetic power of Parret, and certainly none for the druids Drayton mentions in connection with it. Owen

${ }^{21}$ For Drayton's knowledge of Price, see Moore, 789. Observing Drayton's dedicatory epistle, "To my friends, the Cambro-Britans," scholars often assume the poet's rare knowledge of Welsh literature, but refuse to speculate about what that knowledge may have entailed. See for example the notes to Drayton's works, 5:146, 231, 234; Hiller, 3. 
believes Drayton must have consulted, or heard about from someone who had consulted, a poem called the "Arymes Prydein," which was included in the Book of Taliesin. The "Arymes," notes Owen, has seers called "derwyddon" who foresee a battle on the river "Perydon." While Owen admits that "the 'Arymes Prydein' was likely to have had in his [Drayton's] day a very limited circulation," he believes that Drayton had direct or indirect contact with this old Welsh poem. ${ }^{22}$

We may be able to add something to this speculation of Owen's; if Drayton knew of one poem from the Book of Taliesin, perhaps he could have known about more. In Song 4, Drayton, preparing to sing Wales, "Nurse of all the British race" (108), identifies himself with the power of Taliesin: "Fill me a bowle of Meath, my working spirit to raise: / And ere seven Bookes have end, I'le strike so high a string, / Thy Bards shall stand amaz'd with wonder, whilst I sing; / That Taliessen, once which made the Rivers dance, / And in his rapture raiz'd the Mountaines from their trance, / Shall tremble at my Verse, rebounding from the skies; / Which like an earth-quake shakes the Tomb wherein he lies" (112-18). In this striking passage, Drayton wants to view Taliesin as more than a solitary, obscure name. Drayton wants to conceive Taliesin as a true person with whom he seeks communion and to whom he aspires to be an heir; Drayton would be now as the long-dead bard was then: the chief glorifier of the Britons, the purveyor of continuity. But perhaps this strange, personally affected reference to a figure as cloudy as Taliesin bespeaks not only Drayton's attraction to the idea of continuity, but also his knowledge of some of the work ascribed to the hero-bard. For example, why does Drayton announce himself inspired by mead? In a poem of The Book of Taliesin, the persona of Taliesin asks for mead in a similar vein, and declares that bards are inspired by it. Moreover, some larger patterns in the Poly Olbion are reminiscent of the Taliesin persona of the poems in the Book. For example, the ability of Drayton's unique muse to travel everywhere in Britain and see everything, past and present, seems to recall "Taliesin," who is fond of boasting about the miraculous journeys he has made. Moreover, Drayton is full of disdain for the writers and readers of his era, inferior to him for their neglect of public duty, their refusal to celebrate the nation, and their

${ }^{22}$ Owen, 47-48. For the "Arymes Prydein," see Skene, Book of Taliesin poem \#6, 2:123-29, trans. 1:436-42. Owen notes that Skene translates "derwyddon" as "druids," but that Skene's translations are considered somewhat unreliable. 
bad taste; "Taliesin" offers similar criticism of his fellow bards, considering himself above them. ${ }^{23}$ Might these similarities be more than coincidence?

And yet even if this exciting prospect were true that Drayton did know Taliesin as something more than a mere name, he seems to have been unable to hold ancient Welsh poetry as truly capable of establishing continuity. If Owen is correct about the influence of "Arymes Prydein," why is not Drayton more forthcoming about his familiarity with a genuine, prophetic, British poem attributed to his hero, Taliesin? If he did view the Taliesin material as a solution to the antiquarian problem, it seems that Drayton would make much more frequent, and much less covert, use of it.

This interpretation seems justified by Drayton's mention of Taliesin in the midst of Dee's defense in Song 10: "From Taliessen wise (approved so with us, / That when he spake, was held to be oraculous, / So true his writings were) and such immortall men / As this now-waning world shall hardly heare agen / In our owne genuine tongue, that natives were of Wales / Our Geffray had his Brute" (249-54). Taliesin's writings were so true, says Dee, that they were thought "oraculous," foreseeing things to come for the nation, and endowed with a visionary perspective of the pattern of the nation's fate. According to the context of the passage, this power is supposed to be connected somehow to the power to transmit texts; here we are supposedly being told about credible sources for Geoffrey. But we never really get a sense of this connection. Whatever the content of Taliesin's writings, divinely inspired and "true" though they may have been, this truth in them seems to have been of a forward- (rather than backward-) looking strain. That Drayton gives us Taliesin the vates in a place that calls for Taliesin the historian is revealing. While we see that what Drayton actually values in Taliesin is his imagined role as oracle, we also sense that this is his only role. Dee's speech is passionate but vague, upholding only the idea of Taliesin as part of the information chain culminating in Geoffrey. Instead of establish-

${ }^{23}$ For the connection of bards and mead, see Skene, Book of Taliesin poem \#3, 2:115-16, trans. 1:523-25. "Taliesin" also dedicates an entire poem to mead, poem \#19, 2:164-65, trans. 1:538-39. For a good example of a poem which declares the poet's manifold, miraculous experiences and knowledge, see poem \#7, 2:129-37, trans. 1:52533. For Taliesin's reproach of his fellow bards, see for example poem \#3. It should be noted that proclaiming his own omnipresence and rebuking his fellow bards are both characteristics of the Taliesin of the Hanes. 
ing continuity, here Drayton seems to evade the problem of antiquarianism, taking consolation in his ideal of the vates.

Similar to this use of Taliesin is Drayton's use of Merlin: in both cases, while the poet-figure is indeed associated with the transcendence of time, his role as vates is substituted for his role as historiographer, calling into question whether any solution to the antiquarian problem truly exists. ${ }^{24}$ The poet's preoccupation with Merlin spanned his career. For example, in one of his earliest published works, Idea The Shepheards Garland, a collection of eclogues, Drayton has Batte ask Borrill why he sits brooding "like dreaming Merlyn in his drowsie cell" (1:77). In a later eclogue, Gorbo refers to "Welch-wisard Merlyn," an "Oracle" without peer, likened to the "Sooth-saying Sibels" (1:86). Drayton gives Merlin another mention in Peirs Gaveston: during the reign of Arthur, "Merlin ingraved many prophecies" (1:194). When Drayton turned to welcoming the new king, James, into England, he emphasized once more Merlin's prophetic powers: "As theyr great Merlin porpheci'd before / Should the old Brittons regality restore" (1:473). Drayton helped propagate - and ostensibly gave stubborn credence to - the myth that the $\mathrm{Tu}$ dor/Stuart dynasty fulfilled Merlin's prophecy of the Britons' return. Such sentiment was to be repeated in the Heroical Epistles (2:209-10), and then again in the Poly Olbion (5.45-56); although in the latter case only the prophecy is mentioned, Merlin's association with it is certainly inferred. Thus, Drayton had from early on developed a concrete picture in his mind of Merlin the wise old hermit, predicting events that were to come true in Drayton's own era - events that were to establish British glory forever. Merlin was a figure who knew and understood the whole of British history from beginning to end. In an important sense, Merlin represented continuity because of his capacity to circumvent time.

In one particular passage in the Poly Olbion, this transcendence of time associated with Merlin is vividly rendered. In Song 10, admiring the river Conway, Drayton attempts to recreate a scene of the old prophet sharing his knowledge (13-40). Drayton invents a physical presence for Merlin, envisioning his "graver wrinkled brow," the particular place where he spoke, and an audience who actually saw and heard him. It is as if Drayton imagines bimself seeing and hearing Merlin prophesy; just as Merlin can see the future as though it were present - he can see the poet's own time - so can Drayton see Mer-

${ }^{24}$ For Drayton and his ambivalence on Merlinic mythology, see Dobin, 189-94. 
lin himself. Thus, in this connectedness to Merlin we sense Drayton's will to circumvent time. Merlin sees the entire panorama, the completed narrative, of British history, and Drayton sees Merlin; just as he did with Taliesin, with Merlin Drayton seeks communion with an ancient vatic figure, and in this communion we may discern Drayton's monumental urge to imagine continuity.

But at the same time, just as he did with Taliesin, here Drayton presents the vatic Merlin in place of Merlin the historian - an actual writer who produced a text. The "dreadfull words he spake" are "so ambiguous" that the hearers stand "amazed"; Merlin is not easily deciphered. That being the case, how is he an effective link in the chain of information? Are his musings esoteric and occult, purely his own? Though Drayton is obviously attracted to Merlin, he never stresses Merlin's role as a poet and historiographer. Instead, he focuses on the supernatural and fantastic aspects of Merlin the magician and seer. This becomes clear when in the next few lines Drayton goes on to relate something of Merlin's subject matter: the prophetic interpretation he gave to King Vortigern about the fight between the red and white dragons, in which the destruction of the red dragon heralds the fall of Britain (25-37). This, the first of the prophecies of Merlin, did not much credit Merlin or Galfridian mythology, for it involved a patently fabulous story of Merlin and Vortigern observing two real, live dragons. ${ }^{25}$

Indeed, whenever Drayton mentions Merlin in Poly Olbion, he accompanies the magician with the most notoriously fabulous tales associated with him. Twice Drayton refers to the absurd Galfridian myth that Merlin was responsible for Stonehenge (3.55-56, 4.32930). ${ }^{26}$ In Song 4 , he touches on Merlin's plan to construct a "wall of solid brasse," and on how the sorcerer was imprisoned in the ground, beguiled by the "loving of an Elfe" (331-48). The next Song, 5, presents us with an account of Merlin's conception by an incubus, though with a caveat that it is "fayned" (159-77). Moreover, though Selden reminds us of Giraldus's division of the Merlins (89), Drayton's Merlin is never split into two distinct authors, nor does the poet ever refer to him as a source for the British History. Merlin in Poly Olbion is purely the popular Merlin of Arthurian legend. As he 384-97.

${ }^{25}$ For this and Geoffrey's other Merlin prophecies, see Geoffrey of Monmouth,

${ }^{26}$ For Merlin and Stonehenge, see Geoffrey, 410-13. Camden gives more reasonable conjectures, Britain, 251-55; see also Selden, Poly Olbion, 60-61. 
appears in this guise, our impression of him as a serious figure who can link us to the past is much diluted, if not totally vitiated.

Thus, with Taliesin, and with Merlin especially, we sense that Drayton harbors a special admiration for and desire for communion with the vates figure, and that these feelings correspond to the poet's basic wish to transcend the limits of time; we also sense, however, that Drayton ultimately fails to apply such sentiments to the problem of antiquarianism. Writers such as Price had attempted to demystify Merlin and Taliesin and turn them into historiographers, but Drayton seems unable to capitalize on this project. On the one hand, Drayton insists on maintaining the vatic ideal simply because he does not want to part with it; with Merlin and Taliesin providing inspiration for himself, he does not wish to conceive of them without the arcane aura of prophecy surrounding them. But on the other hand, perhaps the poet realized that as historiographers, the two figures simply fell short. In the mundane world of record-keeping, they were sadly deficient. The poet, perhaps, saw that he could not, in any serious way, employ Taliesin and Merlin to confront antiquarianism they had left no historical text - and so instead he embraced them into his own poetic imagination, appropriating them as his own ideal models. With Taliesin and Merlin, as with bards in general, Drayton finally proves unable to contend with antiquarianism.

\section{III}

As far as establishing continuity was concerned, Drayton faced a different problem with druids than he faced with bards. On the one hand, thanks to the classics he knew more specific facts about druids as they existed in the ancient world. On bards, the classics had said little more than that they had existed. ${ }^{27}$ But Caesar and Pliny had reported something of the druids' rituals, beliefs, and social position, and Tacitus had narrated an actual scene involving them: the expedition of Suetonius Paulinus to the island of Mona (Anglesey), in which his men were temporarily shocked by a group of furious druids whom they subsequently slaughtered. ${ }^{28}$ The presence of druids in the ancient world could be more clearly fleshed out than that of the

${ }^{27}$ The only significant fact from out of the classics pertaining to bards is their ability to soothe, with their music, both their own and enemy warriors, thus preventing them from fighting; see Diodorus, 3:179. Drayton relates this magical bardic power over armies, 6.215-19.

${ }^{28}$ Tacitus, 5:155-57. 
bards. On the other hand, the standing of bards as purveyors of culture was much enhanced by the fact of their survival; that they had always been there - i.e., in Wales - gave some credit to the idea that they had passed down the history. The issue with bards was simply whether they had managed - by the Stevtha or some other device for textual editing - to pass on some reasonably accurate form of their lore. But the druids were all dead, and had been dead for quite a while, possibly since the first century A.D. As we have seen, this posed a particular problem for continuity because one of the few facts about druids lent us by Caesar was their practice of keeping the lore to themselves. The conclusion that the lore had vanished with them was hard to avoid, as Camden and his followers noted. In the defenses of Dee and Wye, we observed Drayton's struggle with and anguish over this problem of the druids' demise. If we look at Drayton's remaining passages on druids in the poem, we see more of this type of pattern: the monumental strain is offset by the antiquarian one.

Drayton clearly wants very much to associate druids with continuity. Their derivation from foreign historical sources bothers him, and so, eager to naturalize them, he tries several times to figure them into native British folklore. One example of this we have already seen: the prophecy about the Parret river in Song 3. The phrase "from the Druides time" implies that local people have been whispering a druidical saying to one another for centuries. Also, Drayton's Parret prophecy touches the conflict between the Saxons and the Britons, suggesting either that the druids foresaw the conflict or that they lived to become embroiled in it. Either way, the druids are made a part of the national struggle, given a role to play in the national drama. In Song 6, Drayton fashions another local druidic prophecy: "Plynillimons high praise no longer Muse defer; / What once the Druids told, how great those floods should bee / That here (most mightie Hill) derive themselves from thee" (102-04). Here again, druids are given a voice that has survived, and it is a British voice, one conveying a close relationship with the pulse of the land itself. Later, in Song 12, the poet again affords the druids a vital link with the land, in this case the forest of Arden: "From Arden, in those dayes delivering prophecies. / The Druids (as some say) by her instructed were. / In many secret skills shee had been cond her lere" (500-02). The "as some say" is deliberately misleading; no one says anything of the kind but Drayton himself. The poet feels he must invent for the druids some connection to Britain, some sense that they comprise part of 
the local flavor. We are meant to believe that their resonance is still felt.

Another way Drayton involves druids with continuity is to assert the age and prominence of their learned tradition. In Song 6, Drayton devotes the opening of Wye's long speech to an account of the "native Priests," the "dreadlesse Druides," and how they came from out of Britain to teach all of Gaul "in our rites" - that is, in rarefied British knowledge (210-13, 220-36). ${ }^{29}$ Druids help establish the monumental idea that things British are the oldest and finest around. The very early cultivation of learning in Britain seemed to make the idea of continuity more believable. ${ }^{30}$ Did Britain's time-honored acumen at letters, "so renown'd" throughout the world (236), suddenly disappear? Did the British suddenly turn dumb?

But imagined druidical prophecies and assertions of the druids' anteriority did nothing to change their utter extinction, a fact of which, as we saw in Wye's impassioned defense, Drayton was well aware; and so, when the poet focuses on the druids often their death has a looming presence. In the invocation (to the bards, as we recall), when Drayton speaks of metempsychosis, "as those Druides taught, which kept the British rites," he is careful to remind us that this is a heathen doctrine: "But their opinions faild, by error led awry, / As since cleere truth hath shew'd to their posteritie" (1.35-38). Druidical teaching is wholly foreign to the Christian era; it is of a bygone time. "Faild" is a striking word to apply to the transition from paganism, with its connotations of a complete revolution, of the old "opinions" falling into oblivion.

In Song 8 Drayton turns to Tacitus's grim scene on Mona, where the Britons were subjected to the "utter spoyle" of the Romans (25866). The poet glosses the episode as much as possible, emphasizing that the sight of the "frantick British foes," the "fearlesse Druides," horrified the Roman commander Suetonius and "strooke him pale with dread," as their shrieking disturbed "the troubled heaven." As Hiller notes, Drayton's recasting of the scene does its best to turn the

${ }^{29}$ For the possible founding of druidism in Britain, see Caesar, 337.

${ }^{30}$ For the argument that letters had existed at a very early time in Britain, see for example Bale, 5-7; Harrison, 1:33-36. Both statements are based on the belief that learning first developed in Britain under the Samotheans - a race directly descended from Noah and preceding the arrival of Brutus - whose learned kings included Druis and Bardus. Drayton's failure to mention the Samotheans in Poly Olbion is important to notice, as it may bespeak his suspicions about the limits of continuity. 
druids from victims into heroes. ${ }^{31}$ But while Drayton wants to stress the druids' boldness, and not their annihilation, we sense that annihilation nevertheless. It is as if Drayton finds their fate so unspeakable that he cannot but omit what happens to the druids after they initially scare the Romans; indicated only by the brief phrase "utter spoyle," their destruction must otherwise be left unsaid. It is an omission pregnant with meaning, for what Drayton truly conveys here is his own sorrow at their devastation.

Finally, Drayton toward the end of Song 9 borrows from Pliny to describe one of the druids' sacrificial rituals (415-36). The poet imagines a mood of mystery in the eerie "darke" forests of Mona, as the druids lift "their bloodied hands" to heaven after slaying the white bulls. But Mona herself, who has narrated the scene, leaves us with a reminder that it is a spectacle of the past, her awesome mysteries unable to prevent her from being overrun by the Romans and English, so totally that she lost her name: the English "Gave me this hateful name, which I must ever bear, / And Anglesey from them am called everywhere" (435-36). "Mona" is no longer "Mona, Insula Druidum"; it is now Anglesey, and druids no longer haunt its groves. ${ }^{32}$ This mournful notion that Celtic place names have long since been supplanted recurs in Poly Olbion in several places, and its message is unmistakable: although bound to deny it, the poet is aware that connection with Britain's Celtic past has been irretrievably severed. ${ }^{33}$ Thus Drayton seems grudgingly to have suspected that the fact that the druids were learned men in Britain when the Romans came in itself could not prove that they had had any hand in the British history; their tracks had long since been erased.

What we must realize is that because of this idea of extinction, Drayton identified much more closely with druids than even Hiller has noted. For Drayton, the idea of a history never written was the most awful prospect imaginable; the monumental historian in him shuddered to think that future ages would be kept from hearing about the heroic deeds of their ancestors. This is why Drayton, in his bitter epistle "To any that will read it," which opens the second in-

\footnotetext{
${ }^{31}$ Hiller, 7-8.

${ }^{32}$ Humphrey Lhuyd's treatise "De Mona Druidum Insula" influenced Drayton; see Moore, 789.

${ }^{33}$ See Poly Olbion 8.428-31; 16:145-216.
} 
stalment, ${ }^{34}$ curses the unreceptive upper-class public which has frowned on his attempt to glorify them: "I wish it may be hereditary from them to their posteritie, that their children may bee beg'd for Fooles to the fift Generation, untill it may be beyond the memory of man to know that there was ever any other of their families." Loss of memory about their own past - this is the worst fate Drayton can wish for his apathetic Jacobean readership. Drayton feared that his own efforts at maintaining continuity, at forging another link in the chain, were falling on deaf ears, with his own historical poem threatening to become a history never written.

Drayton, as critics like Hardin have seen, felt his own belatedness; he felt that he was the creature of another time, a stranger in an era with no feelings sympathetic to his own. ${ }^{35}$ This is perhaps why throughout Poly Olbion the poet shows such a preference for native British extinct and endangered species: he often reminds us of the hapless Britons, struggling to survive the onslaught of the invaders, and eking out an obscure life in his land's remaining nooks and cranies; he devotes a large section in Song 6 to the beavers of the Tivy river (56-86), so crafty in their fortifications against ravaging hunters, although he knows that by his own time they had been wiped out; he accompanies nearly every account of an ancient ruin or stone monument with a lament about the ravages of time; and he dwells on the depletion of England's mighty forests. ${ }^{36}$ For Drayton, an age that cares nothing for the upkeep of its forests is an age with no feelings for monumental continuity, an age "senselesse of the good of their posterities" (3.152). No wonderful British thing should have to die out and turn into an anachronism; but it seemed that many such things, like the druids, already were, and that many others - like Drayton himself - were threatened to be.

Drayton was a man fixated on a medieval historical ideal of stability and continuity in an era which was discovering a modern historical consciousness. The challenge of the antiquarians was a belief in anachronism: they asked readers to accept that things had changed,

${ }^{34}$ For the poor reception of the first installment of Poly Olbion, and Drayton's disappointment, see Newdigate, 158-62; Hebel, Preface to Poly Olbion, viii-x.

${ }^{35}$ See Newdigate, 127-35; Hardin, 85-115; Helgerson, 120-46.

${ }^{36}$ Passages on the harried Britons include: 6.237-251, 9.188-92, 11.154-71, 16.198200, 213-16, 27.312-18, 30.301-08. Drayton's beavers come from Giraldus Cambrensis, 106-09. Passages on ruins which convey laments on time include: $1.202-03,3.53-64$, 3.301-06, 21.5-16, 30.326-27. Passages against deforestation include: 3.149-56, 7.259-300, $13.247-52,17.379-408,19.26-66,22.1603-31,26.107-48$. 
and that our knowledge of British life in times prior to those changes was severely limited. Drayton acknowledged the antiquarians and many were his friends, but their notion of anachronism was hateful to him and he struggled against it, using the best tools at his command: bards and druids. Borrowing the bards and druids from classical history, the poet drew upon them in order to assume a secret, mysterious continuum of information passed on through the centuries - a continuum that would respond to the antiquarian need for an explanation of why a history should be accepted. This study has argued that on some level Drayton recognized, and was saddened by, his inability to prevail in this struggle to imagine continuity. British history began with Julius Caesar and belonged wholly to the Romans until Gildas and Bede. The history was never written.

\section{MARQUETTE UNIVERSITY}

\section{Bibliograpby}

Bale, John. Illustrium Majoris Britanniae Scriptorum Hoc est, Angliae, Cambriae ac Scotiae Summarium. 1558.

Brinkley, Roberta Florence. Artburian Legend in the Seventeenth Century. London, 1967.

Buchanan, George. Rerum Scotiarum Historia. Edinburgh, 1582.

Caesar, Julius. The Gallic War. Trans. H.J. Edwards. Cambridge, MA, 1986.

Camden, William. Britain. Trans. Philemon Holland. London, 1610.

-. Remains Concerning Britain. Ed. R.D. Dunn. Toronto, 1984.

Churchyard, Thomas. The Worthiness of Wales. Spenser Society \#20, 1876.

Crawley, Robert Ralston Crawley. "Drayton's Use of Welsh History." Studies in Philology 22 (1925): 23455.

Daniel, Samuel. The Collection of the History of England. Ed. Alexander B. Grossart. The Complete Works in Prose and Verse of Samuel Daniel. Vol. 4. London, 1885.

Diodorus Siculus. Diodorus Siculus. 12 vols. Trans. C.H. Oldfather. Cambridge, MA, 1933.

Dobin, Howard. Merlin's Disciples: Prophecy, Poetry, and Power in Renaissance England. Stanford, 1990.

Drayton, Michael. The Works of Michael Drayton. 5 vols. Ed. J. William Hebel. Oxford, 1961.

Elton, Oliver. Michael Drayton: A Critical Study. New York, 1966.

Ferguson, Arthur B. Utter Antiquity: Perceptions of Prebistory in Renais. sance England. Durham, 1993.

Ford, Patrick K., ed. The Mabinogi and other Welsh Tales. Berkeley, 1977.

—. ed. Ystoria Taliesin. Cardiff, 1992.

Geoffrey of Monmouth. The Historia Regum Britanniae of Geoffrey of Monmouth. Ed. Acton Griscom. London, 1929.

Gildas. The Ruin of Britain and other Works. Ed. and trans. Michael Winterbottom. London, 1978.

Giraldus Cambrensis. The Itinerary Through Wales and the Description of Wales. Trans. Sir Richard Colt Hoare. London, 1930. 
Grundy, Joan. The Spenserian Poets: $A$ Study in Elizabethan and Jacobean Poetry. New York, 1969.

Hardin, Richard F. Michael Drayton and the Passing of Elizabethan Eng. land. Lawrence, KS, 1973.

Harrison, William. Description of Eng. land. In Holinshed's Chronicles: Eng. land, Scotland, and Ireland. Vol. 1. New York, 1976.

Helgerson, Richard. Forms of Nationhood: The Elizabethan Writing of England. Chicago, 1992.

Herendeen, Wyman $\mathrm{H}$. "Wanton Discourse and the Engines of Time: William Camden - Historian among Poets Historical." In Renaissance Rereadings: Intertext and Context, ed. Maryanne Cline Horowitz, Anne J. Cruz, and Wendy A. Furman, 142-58. Urbana, 1988.

Hiller, Geoffrey G. "'Sacred Bards' and 'Wise Druids': Drayton and his Archetype of the Poet." ELH 51 (1984): 1-15.

Jonas, Leah. The Divine Science: The Aesthetic of some Representative Seventeenth Century English Poets. New York, 1940.

Kendrick, T. D. The Druids: A Study in Keltic Prebistory. New York, 1927.

—. British Antiquity. London, 1950.

Lhuyd, Humphrey. The Breviary of Britayne. Trans. Thomas Twyne. 1573.

Lucan. Lucan. Trans. J. D. Duff. Cambridge, MA, 1988.

Leland, John. The Assertion of King Artbure. Trans. Richard Robinson. In The Famous Historie of Chinon of England by Christopher Middleton together with The Assertion of King Arthure, ed. William Edward Mead. London, 1925.

McEachern, Claire. The Poetics of $\mathrm{Na}$. tionbood. Cambridge, 1996.

Moore, William H. "Sources of Drayton's Conception of Poly Olbion." Studies in Philology 65 (1968): 783-
803.

Newdigate, Bernard H. Michael Drayton and bis Circle. Oxford, 1941.

Owen, A.L. The Famous Druids: $A$ Survey of Three Centuries of English Literature on Druids. Oxford, 1962.

Parry, John Jay, ed. and trans. Vita Merlini. University of Illinois Studies in Language and Literature, 10 (1925).

Piggot, Stuart. The Druids. New York, 1968.

Pliny. Natural History. 10 vols. Trans. H. Rackham et al. Cambridge, MA, 1967.

Pocock, J.G.A. The Ancient Constitution and the Feudal Law. Cambridge, 1987.

Powel, David. Introduction. The Historie of Cambria, now called Wales. 1584.

Price, John. Historiae Brytannicae Defensio. London, 1573.

Selden, John. Jani Anglorum Facies Altera. London, 1610.

-. Analecton Anglo-Britannicon. Ed. David Wilkins. Opera Omnia. Vol. 2. London, 1726.

Skene, William F., ed. and trans. The Four Ancient Books of Wales. 2 vols. Edinburgh, 1868.

Speed, John. The History of Great Britaine. London, 1650.

Spenser, Edmund. A View of the State of Ireland. Ed. J. Payne Collier. The Works of Edmund Spenser. Vol. 5. London, 1873.

Strabo. The Geograpby of Strabo. 8 vols. Trans. Horace Leonard Jones. Cambridge, MA, 1988.

Tacitus. Tacitus. 5 vols. Trans. John Jackson. Cambridge, MA, 1981.

Twyne, John. De Rebus Albionicis, Britannicis, atque Anglicis, Commentariorum libri duo. London, 1590.

Vergil, Polydore. Polydore Vergil's Eng. lish History, vol. 1 (Books 1-8). Ed. Sir Henry Ellis. London, 1866. 